Article

\title{
Quality of Sugar Beets under the Effects of Digestate Application to the Soil
}

\author{
Andrzej Baryga ${ }^{1}$, Bożenna Połeć ${ }^{1}$ and Andrzej Klasa ${ }^{2, *}$ \\ 1 Institute of Agricultural and Food Biotechnology, ul. Rakowiecka 36, 02-532 Warszawa, Poland; \\ baryga@poczta.onet.pl (A.B.); bozenna.polec@ibprs.pl (B.P.) \\ 2 Department of Agricultural Chemistry and Environmental Protection, University of Warmia and Mazury in \\ Olsztyn, ul. Oczapowskiego 8, 10-519 Olsztyn, Poland \\ * Correspondence: aklasa@uwm.edu.pl; Tel.: +48-523-4705
}

Received: 8 October 2020; Accepted: 31 October 2020; Published: 3 November 2020

check for updates

\begin{abstract}
Management of digestate from production of biogas has a great environmental importance. One of feedstock for biogas generation is beet pulp, a side product of sugar beet processing plant. In the paper a closed loop of beet pulp utilization at sugar beet plantation is presented. Effects of soil application of digestate obtained from digestion of sugar beet pulp were compared with standard mineral fertilizers. The field experiment was performed in three successive growing seasons. The studies were concentrated on quality of sugar beets grown under effects of two fertilization treatments-soil application of digestate cv. standard mineral fertilizers. It was found that some important quality indices (weight of single sugar beet root, content of sucrose in root tissues) were higher for beet harvested from digestate treatment compared to standard mineral fertilization (control). The concentration of harmful component (amide nitrogen) in sugar beets grown under conditions of digestate soil application was lower than in the control. It can be concluded that soil application of digestate from processing of sugar beet pulp can be treated as environmentally sound and effective method of its management.
\end{abstract}

Keywords: gasifier; digestate; sugar beet; beet pulp; beet quality parameters

\section{Introduction}

Beet pulp, a by-product of sugar factories for many years, has been used as feed of high nutritional value, especially for dairy cows. However, recently noted considerable reduction of cattle number in Poland as well as breaking ties between crop and animal production in many farms, made in a sugar beet processing plants urgent necessity of finding an alternative and effective method for beet pulp management.

One of alternatives with high potential from economical as well as from an environmental aspect seems to be processing of pulp in gasifiers.

In the Institute, research works have been carried out to develop technology of anaerobic digestion of sugar beet pulp to produce biogas of high calorific value [1].

Digestion of plant wastes as stock material is a common practice in many countries [2-9] and the final product of digestion i.e., biogas is a valuable source of renewable energy which can be converted to heat, power or to liquid fuels. Under optimal conditions during the course of the gasification process biogas contains: $25-85 \%$ of methane, $14-48 \%$ carbon dioxide, $0.08-0.5 \%$ hydrogen sulphide, $0-5 \%$ hydrogen, $0-2.1 \%$ carbon monoxide, nitrogen $0.6-7.5 \%$ and $0-1 \%$ of oxygen. Final composition of biogas depends on the kind of stock material introduced to the installation and applied method of gasification [10,11]. 
Calorific value of methane amounts to $9470 \mathrm{kcal} \mathrm{m}^{-3}\left(39.7 \mathrm{MJ} \mathrm{m}^{-3}\right)$ what means that biogas of $62 \%$ of methane content shows calorific value of $22.1 \mathrm{MJ} \mathrm{m}^{-3}$ what corresponds to $0.5 \mathrm{~m}^{-3}$ of natural gas; $0.7 \mathrm{~L}$ of diesel, $0.8 \mathrm{~kg}$ of fuel coke; $0.7 \mathrm{~L}$ of gasoline; $1.2 \mathrm{~kg}$ of hard coal or $2.2 \mathrm{~kg}$ of wood [12,13].

Biogas generation is one of the most quickly developing sectors of renewable energy in Poland. At the moment in our country are operating more than 130 biogas installations of total capacity of almost 77 MWe. It has to be mentioned that number of gasifiers processing wastes into biogas is rather low and therefore nowadays they cannot be treated as an important option in national waste management system [14].

It has to be pointed out that biogas is not the only product of anaerobic digestion of organic wastes but solid and liquid side products are inevitably generated during gasification. Wastes from gasifiers contain considerable amounts of important nutrients i.e., phosphorus, nitrogen and calcium. Because of the fact that high quantity of digestate is generated in each gasifier and of its high content of plant nutrients it have to be managed using safe and effective methods.

There are many reports presenting different methods of digestate management with special attention to their environmental safety and cost effectiveness [15-19]. It was mentioned that proper management of digestate sometimes determines profitability of the whole investment [20].

Because in accordance with all European and Polish national law regulations, high level of recycling and reuse of wastes is required and due to the fact that the number of gasifiers is constantly growing, developing environmentally accepted and cost-effective methods of digestate management is urgently needed. Experience gained in other countries revealed that the simplest possible option i.e., soil application of digestate can be treated as the most common method of this waste management especially when fields are located in the vicinity of biogas plant and transportation cost can be avoided.

It has to be noted that soil application of digestate which contains considerable concentration of nutrients in plant available forms can at least partially supplement commercial fertilizers [21].

This simple method of digestate utilization diminishes negative impact of wastes on water quality because nitrogen and phosphorus responsible for eutrophication are taken up by crops and mineral fertilizers rates can be reduced what actually protect surface water [22].

There is a report of using digestate from biogas plant processing maize and sugar beet silage as effective bio-fertilizer in agriculture [23].

Replacing conventional fertilizers by waste substances generated in biogas plants can bring substantial economic effects for sugar beet growers because in the structure of production cost fertilizers amount to $28 \%$ of the total cost [24] and the total cost of fertilizers in sugar beet production was reported to 1300 PLN $(1 € \approx 4.3$ PLN) [25].

\section{Materials and Methods}

Studied material was digestate generated from gasification of sugar beet pulp and sugar beets (Beta vulgaris cv. Fighter) collected from experimental plots.

Research works were conducted at experimental field owned by the Institute in three growing seasons i.e., 2013, 2014 and 2015.

Area of single plot was $18.75 \mathrm{~m}^{2}$ and the field trial was performed in triplicate in modified Latin square design with buffer zones (any variability of soil conditions has been detected).

Two treatments have been studied-standard complex fertilizer application at the rate of $120 \mathrm{~kg} \mathrm{~N} \mathrm{ha}^{-1}$ and digestate in the form mixture of liquid and solid fractions taken directly from the installation every season in the rate equivalent to nitrogen in fertilizers.

Samples of sugar beet roots were taken (30 roots from each treatment every year) and their technological parameters were assessed in the laboratory of the Institute.

The following methods have been used during the course of the experiment: dry matter balance method (National standard PN-EN 12880:2004) [26], ammonia nitrogen-Kiejdahl's distillation (National standard PN-EN 13342:2002) [26], $\alpha$-amino acid nitrogen-spectrophotometry [26], amide nitrogen — titration in water steam [26], concentration of the following metals: sodium, potassium, 
cadmium, copper, lead, nickel, chromium, zinc by ASA spectrophotometry (National standard (FAAS) [26], mercury-by ASA with amalgamate (international standard 2014-EN 13346:2002) [26], sucrose-polarimetry [26], presence of Salmonella pathogens and number of living eggs of intestinal parasites: Ascaris sp., Trichuris sp., Toxocara sp. by standard microscopic methods.

Experimental results were analysed by Statistica®ver. 12.0 PL software (Cracow, Poland) in two-factorial design of ANOVA using Fisher's test $(\mathrm{P} \leq 0.05)$ and presented as homogenous groups.

\section{Results and Discussion}

In Poland, there are not environmental regulations specific for soil application of digestate and therefore herein law regulations for soil application of sewage sludge were taken into account. These regulations were issued in Poland by Minister of the Environment on 6 February 2015. These regulations concern sludge parameters but not having specific regulations parameters of digestate were compared to permissible levels required for sewage sludge application and presented in Table 1.

Table 1. Quality parameters of digestate applied in the experiment on the background of permissible level of potential pollutants allowing soil application of sewage sludge in crop production.

\begin{tabular}{|c|c|c|c|c|c|}
\hline \multirow{2}{*}{ Parameters } & \multirow{2}{*}{ Units } & \multicolumn{3}{|c|}{ Seasons of Studies } & \multirow{2}{*}{$\begin{array}{c}\text { Permissible } \\
\text { Level * }\end{array}$} \\
\hline & & 2013 & 2014 & 2015 & \\
\hline $\mathrm{pH}$ & $\mathrm{pH}$ & 7.8 & 7.5 & 7.6 & - \\
\hline Dry matter (DM) & $\mathrm{g} \mathrm{kg}^{-1}$ fresh weight & 25 & 5 & 3 & - \\
\hline Organic substances & $\mathrm{g} \mathrm{kg}^{-1} \mathrm{DM}$ & 558 & 516 & 309 & - \\
\hline Cadmium $(\mathrm{Cd})$ & $\mathrm{mg} \mathrm{kg}^{-1} \mathrm{DM}$ & 2.7 & 2.2 & 5.2 & $\leq 20$ \\
\hline Lead $(\mathrm{Pb})$ & $\mathrm{mg} \mathrm{kg}^{-1} \mathrm{DM}$ & 17.1 & 42.4 & 22.1 & $\leq 750$ \\
\hline Nickel (Ni) & $\mathrm{mg} \mathrm{kg}^{-1} \mathrm{DM}$ & 5.5 & 8.8 & 5.5 & $\leq 300$ \\
\hline Chromium (Cr) & $\mathrm{mg} \mathrm{kg}^{-1} \mathrm{DM}$ & 29.6 & $<25.0$ & 26.3 & $\leq 500$ \\
\hline Mercury (Hg) & $\mathrm{mg} \mathrm{kg}^{-1} \mathrm{DM}$ & 0.543 & 0.357 & 0.426 & $\leq 16$ \\
\hline Copper $(\mathrm{Cu})$ & $\mathrm{mg} \mathrm{kg}^{-1} \mathrm{DM}$ & 108 & 88 & 115 & $\leq 1000$ \\
\hline Zinc $(\mathrm{Zn})$ & $\mathrm{mg} \mathrm{kg}^{-1} \mathrm{DM}$ & 446 & 295 & 470 & $\leq 2500$ \\
\hline Calcium (Ca) & $\mathrm{g} \mathrm{kg}^{-1} \mathrm{DM}$ & 129 & 82 & 134 & - \\
\hline Magnesium $(\mathrm{Mg})$ & $\mathrm{g} \mathrm{kg}^{-1} \mathrm{DM}$ & 4.02 & 8.4 & 11.4 & - \\
\hline Kjeldahl's total nitrogen $(\mathrm{N})$ & $\mathrm{g} \mathrm{kg}^{-1} \mathrm{DM}$ & 138.4 & 170.4 & 207.0 & - \\
\hline Total phosphorus $(\mathrm{P})$ & $\mathrm{g} \mathrm{kg}^{-1} \mathrm{DM}$ & 12.6 & 15.9 & 12.6 & - \\
\hline Total potassium (K) & $\mathrm{g} \mathrm{kg}^{-1} \mathrm{DM}$ & 10.3 & 11.9 & 12.3 & - \\
\hline Salmonella & in $100 \mathrm{~g}^{-1} \mathrm{DM}$ & none & none & none & 0 \\
\hline $\begin{array}{l}\text { Living eggs of parasites: } \\
\text { Atrichuris sp., Trichuris sp., } \\
\text { Toxocara sp. }\end{array}$ & & none & none & none & 0 \\
\hline
\end{tabular}

It can be stated that in any single case level of potential soil contaminant in applied digestate was not exceeded and this waste can be used as amendment in appropriate rates limited only by content of nitrogen.

As for other crops also to obtain high yield of sugar beet weather conditions play an essential role. On Figures 1-3 patterns of most important weather parameters are presented. It can be seen that seasons of the study were variable as far as presented weather parameters are concerned. 


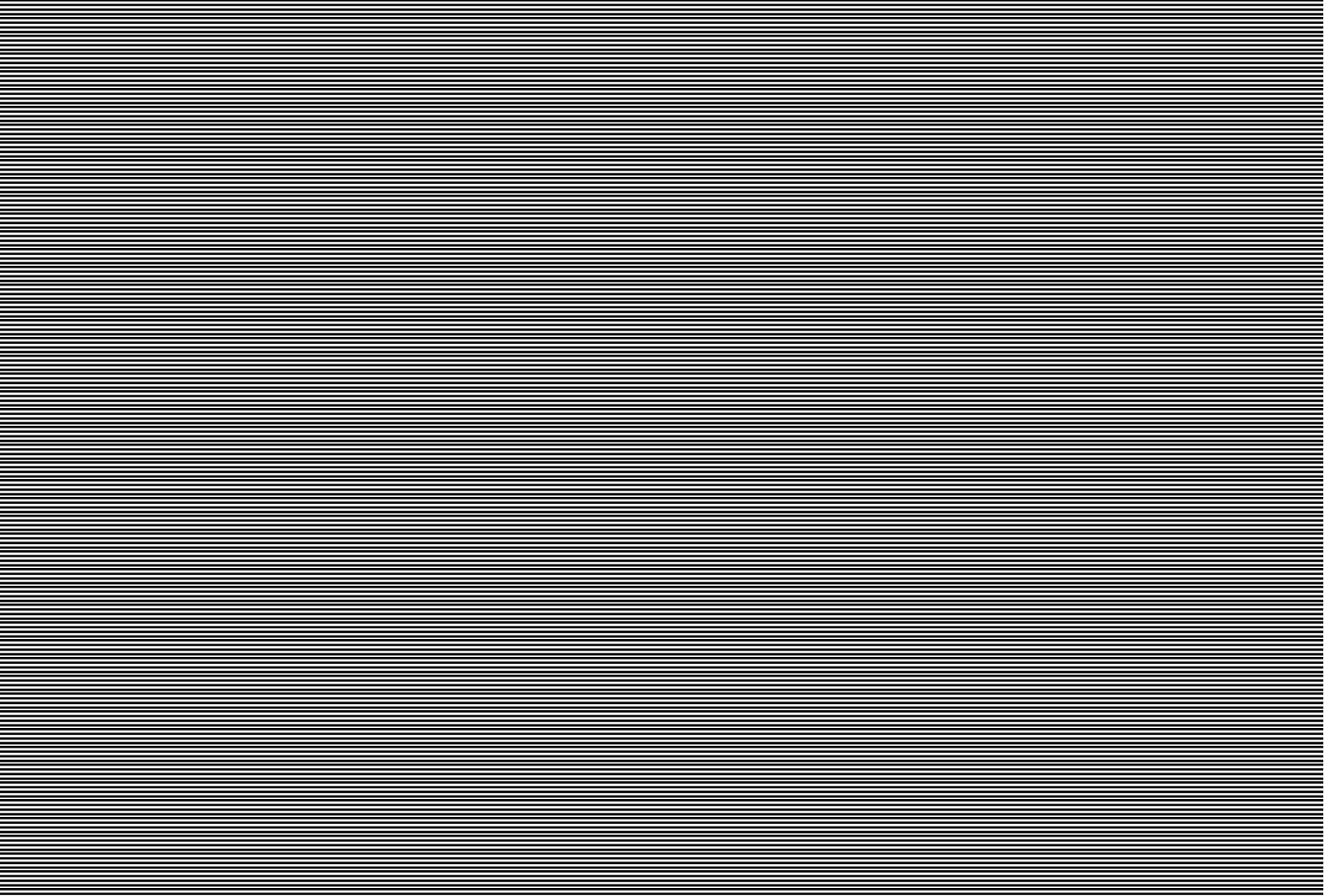

Figure 1. Mean monthly temperature in sugar beet growing season in the period of studies.

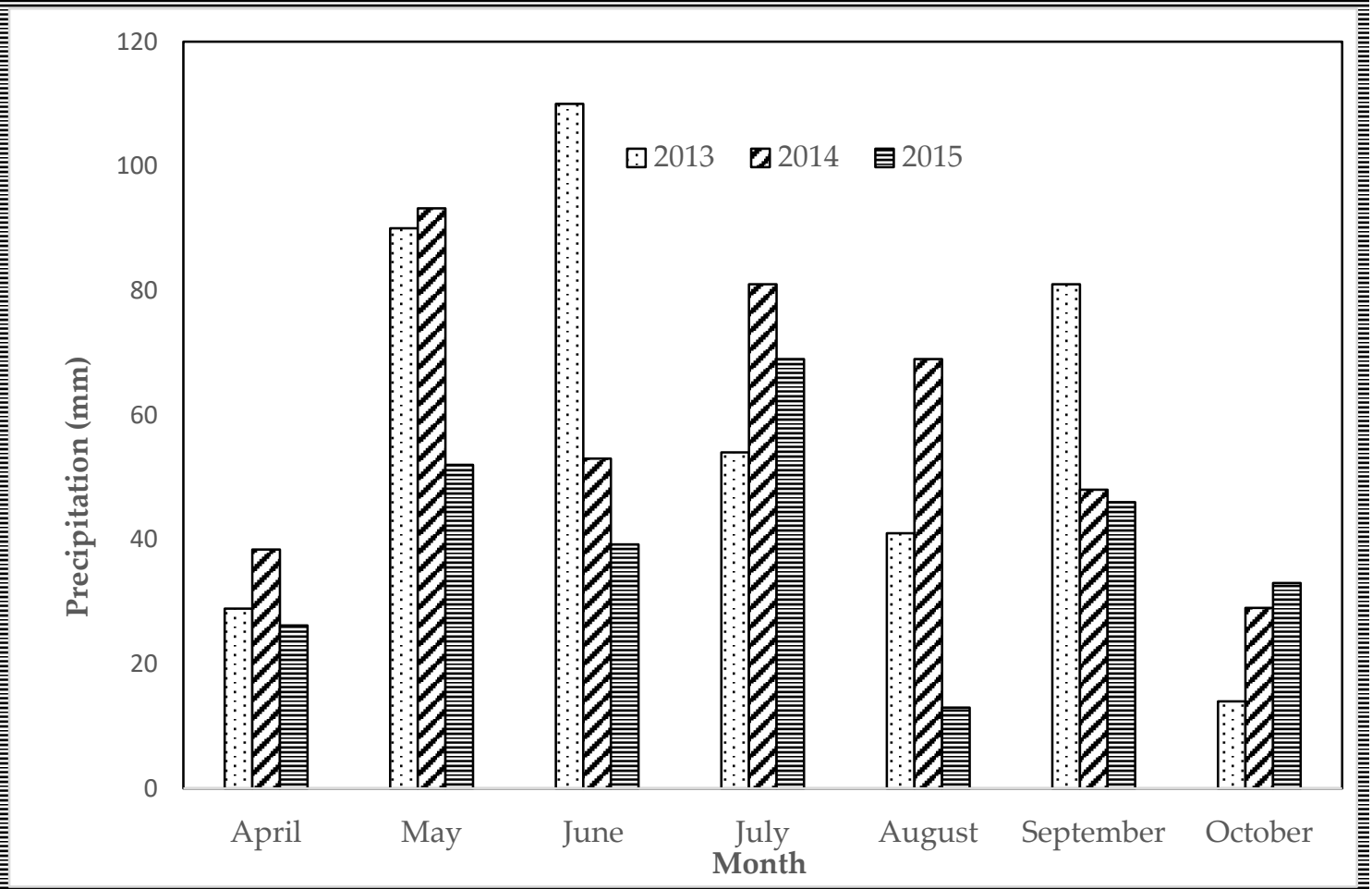

Figure 2. Sum of monthly precipitation in sugar beet growing season in the period of studies. 


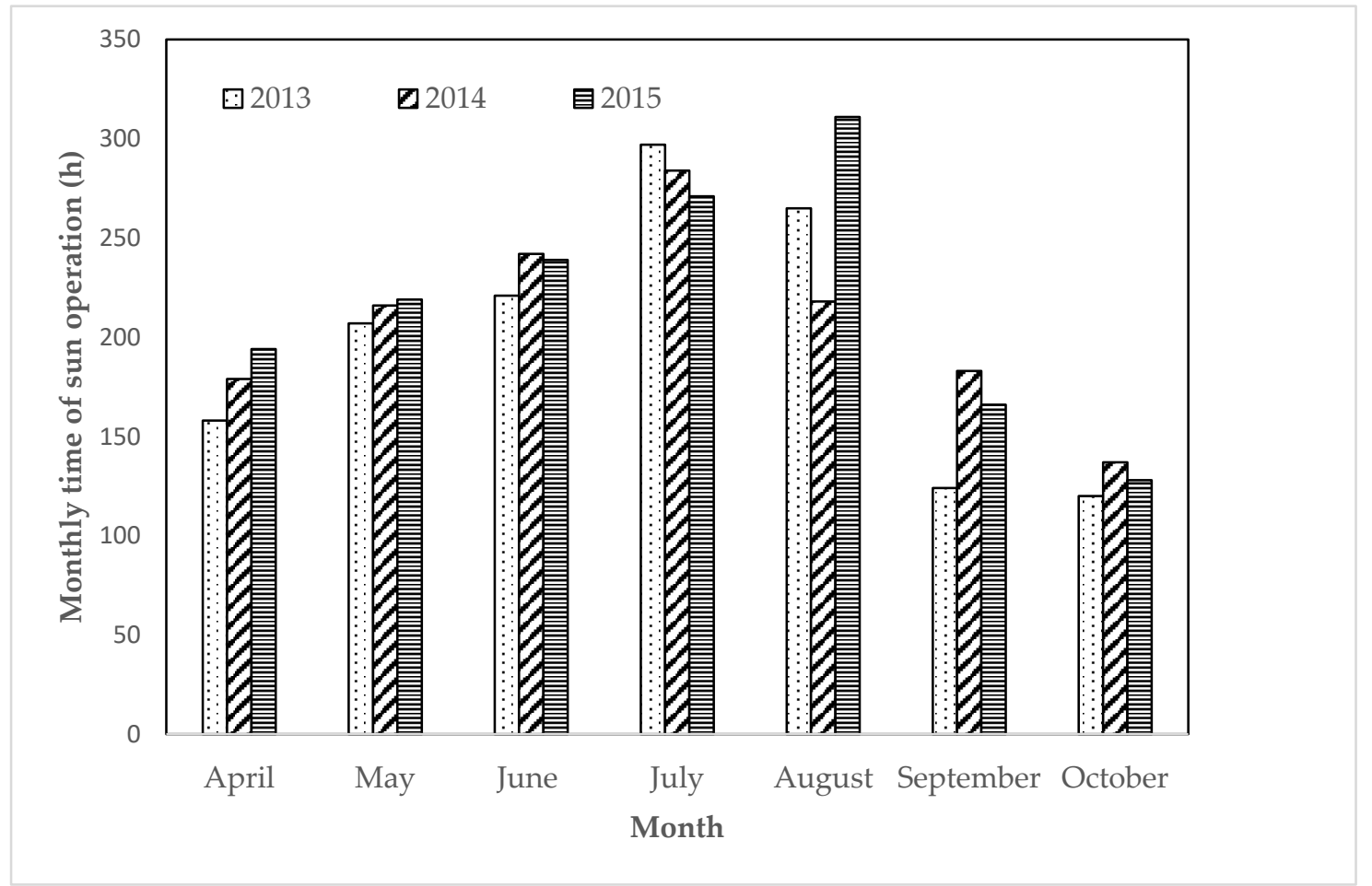

Figure 3. Sum of monthly hours of solar radiation period in sugar beet growing season in the period of studies.

Sugar beet is a crop of high water requirements and for high yields it needs appropriate pattern of temperature during growing period In early phases of plant growth (April-May) water availability and appropriate temperature are critical factors, while insolation has a minor importance. When weather conditions at this phase are optimal growing period lasts longer.

Weather requirements of sugar beet in the phase of crop intensive growth (June-October) are more complex. Biomass accumulation in the roots is highly dependent on temperature and high level of soil moisture, whereas for sucrose accumulation dominant role plays high insolation rate. When at that time number of hours with direct sun radiation is high, sugars are accumulated intensively whereas high precipitation in this period reduce sugar content.

Therefore, it can be concluded that the appropriate pattern of weather condition for sugar beet growth in the initial growth phase occurred in 2013 but in the season 2015 in this period sugar beets met worse conditions. In the season 2013, weather also favoured accumulation of biomass in roots, contrary to 2014. When solar radiation period at the phase of sugar accumulation in roots in studied growing seasons was compared, it can be stated that all three seasons was almost equal.

For growers studied parameters of technological quality of sugar beets are not so important because from their point of view yield and sugar content are crucial.

Contrary, for sugar factory, all presented below sugar beets quality parameters have a key importance because they determine technological value of stock materials i.e., sugar beets for processing.

Results presented on Figures 4-11 show that tested major parameters were affected by the season (factor A) and also by fertilization treatments (factor B). In the all graphs, lower-case letters designate homogeneous group of mean values for factor $\mathrm{B}$ and interaction $\mathrm{A} \times \mathrm{B}$; whereas capital letters point significant difference for factor A. 


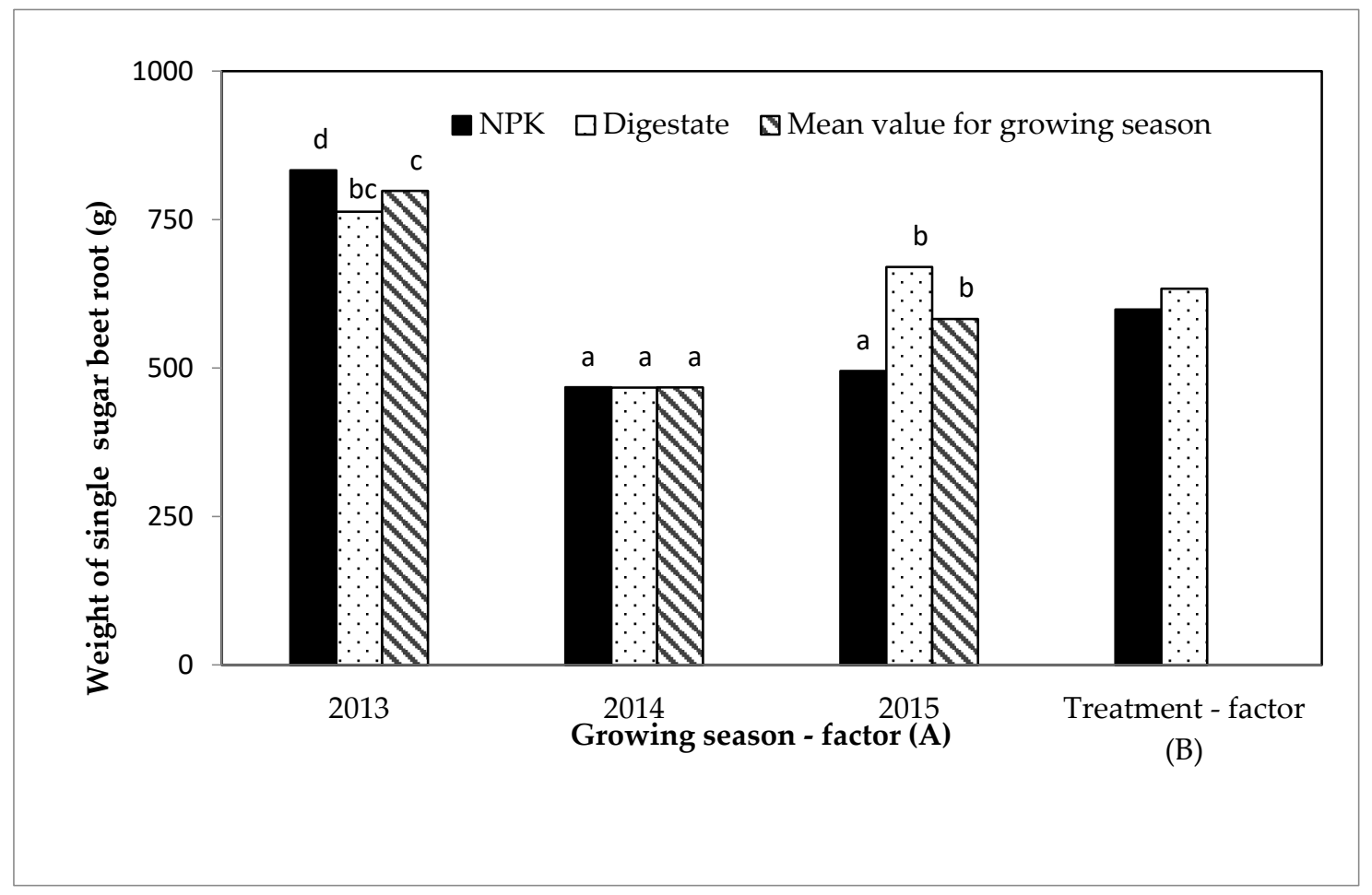

Figure 4. Effects of growing seasons and fertilization treatments on weight of single sugar beet root.

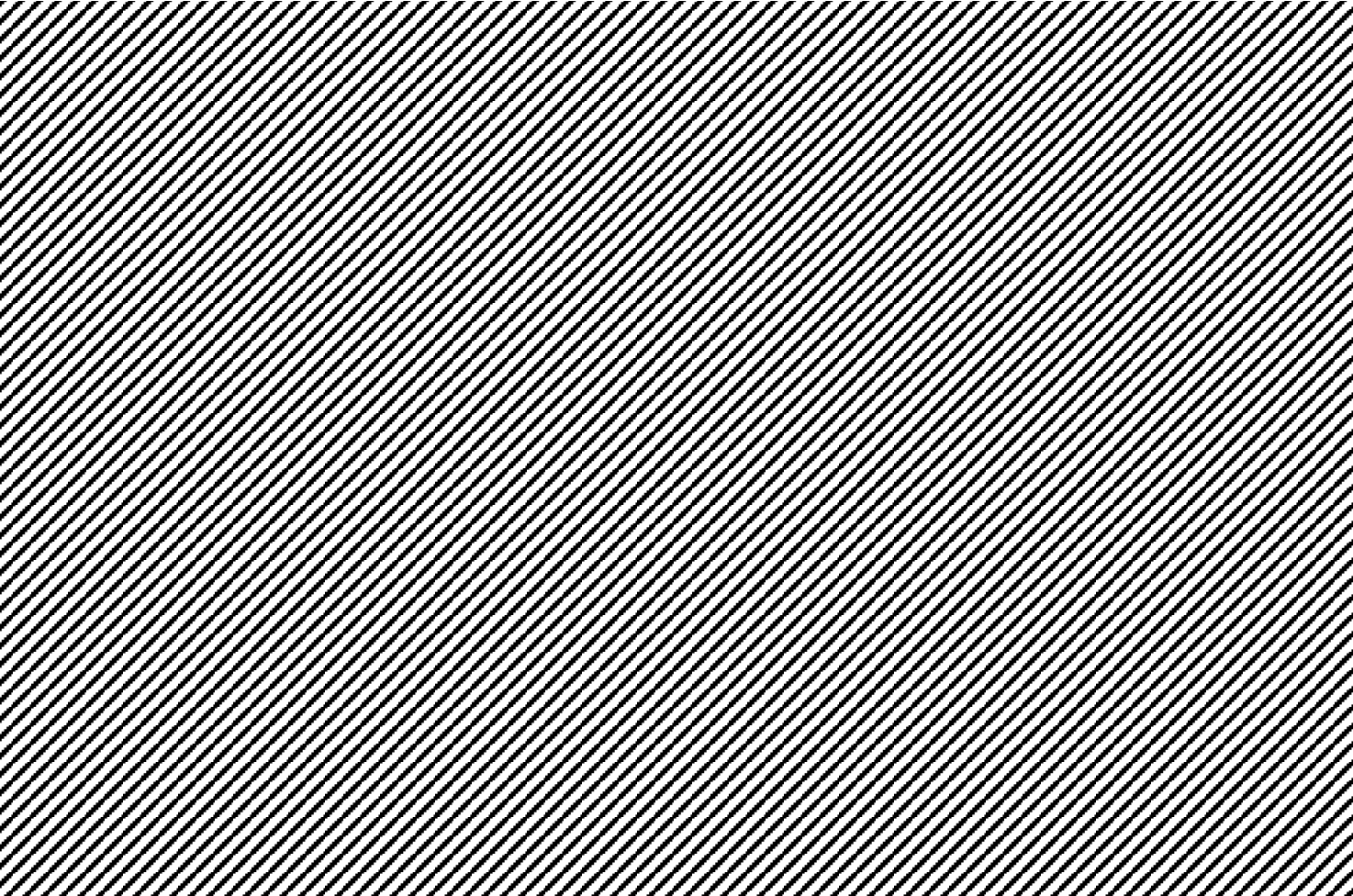

Figure 5. Effects of growing seasons and fertilization treatments on concentration of sucrose in sugar beet roots. 


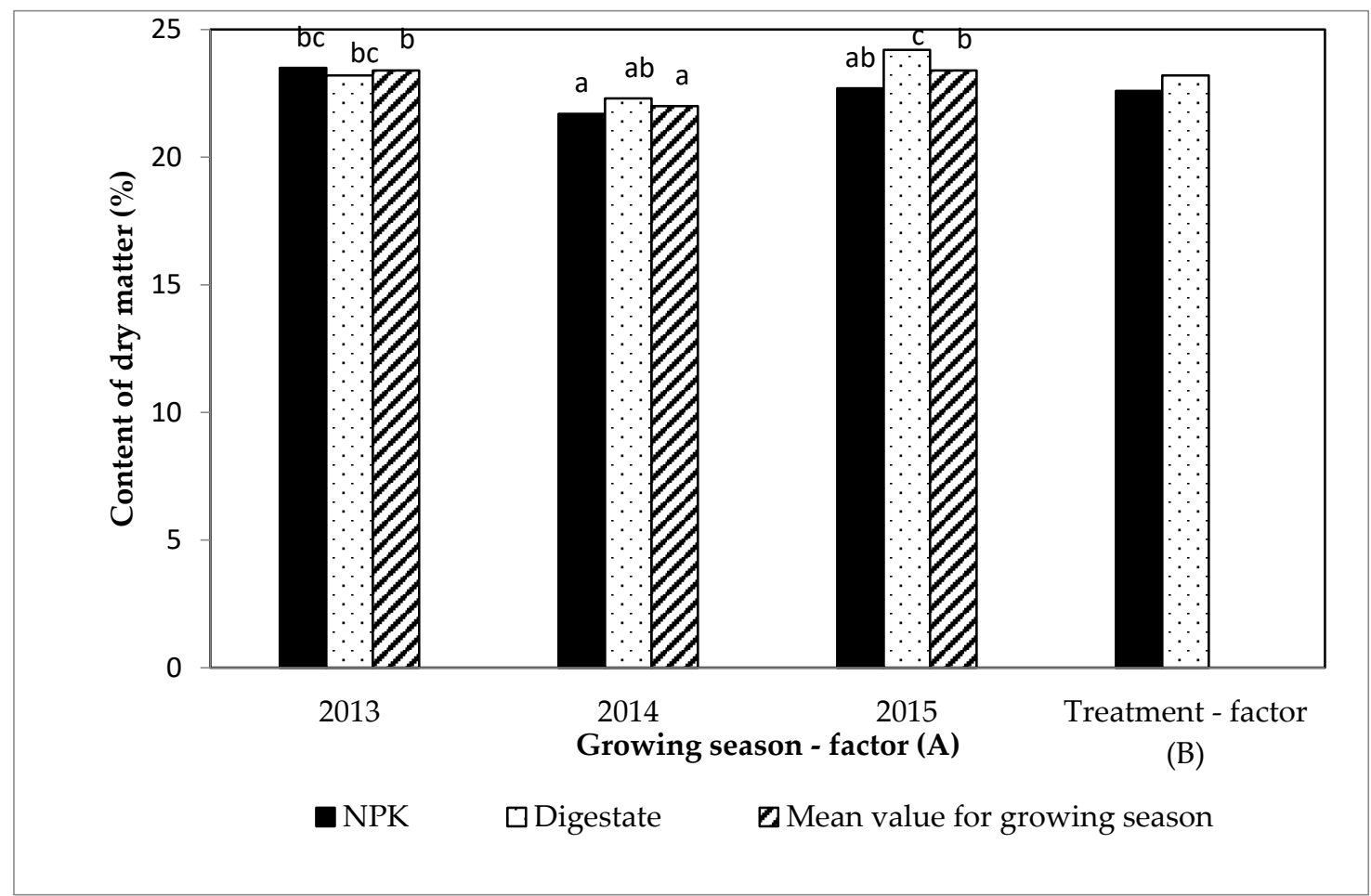

Figure 6. Effects of growing seasons and fertilization treatments on content of dry matter in sugar beet roots.

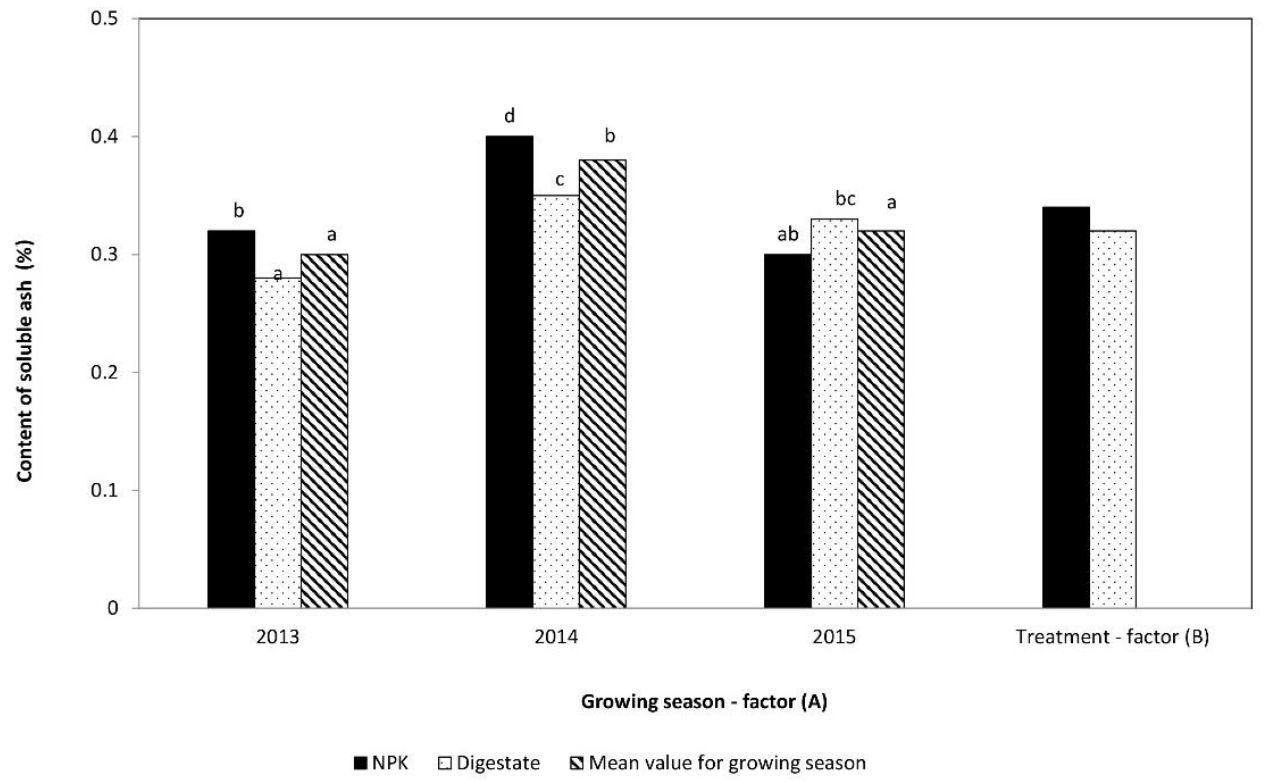

Figure 7. Effects of growing seasons and fertilization treatments on content of soluble ash in sugar beet roots. 


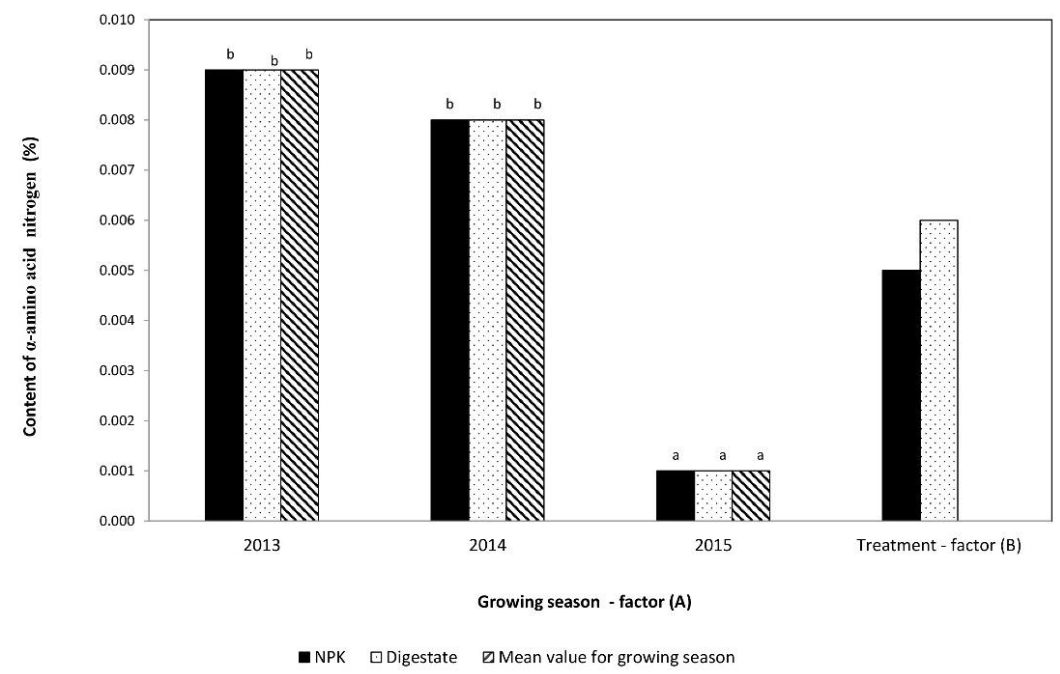

Figure 8. Effects of growing seasons and fertilization treatments on content of $\alpha$-amino acids nitrogen in sugar beet roots.

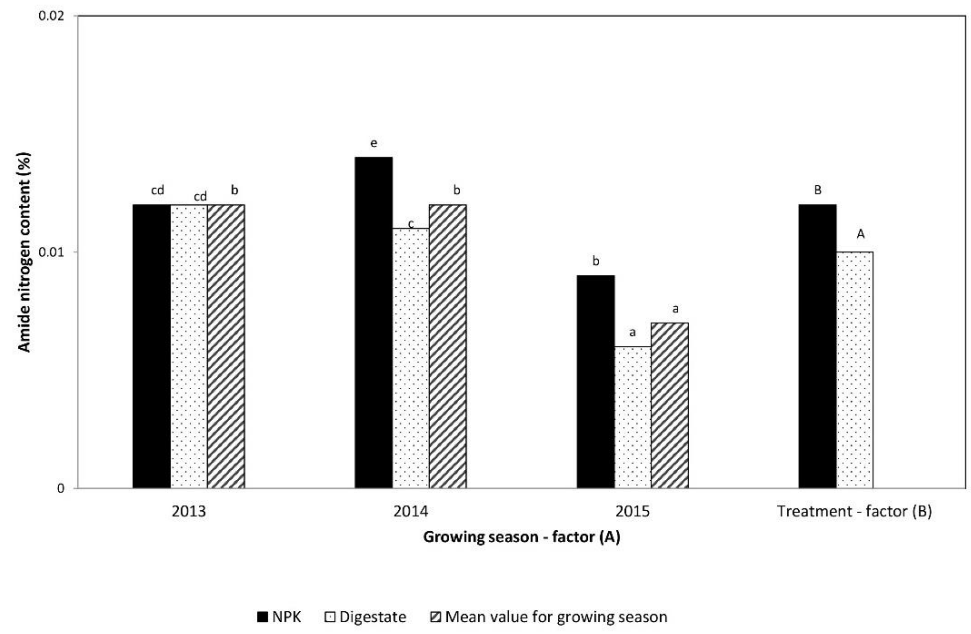

Figure 9. Effects of growing seasons and fertilization treatments on content of amide nitrogen in sugar beet roots.

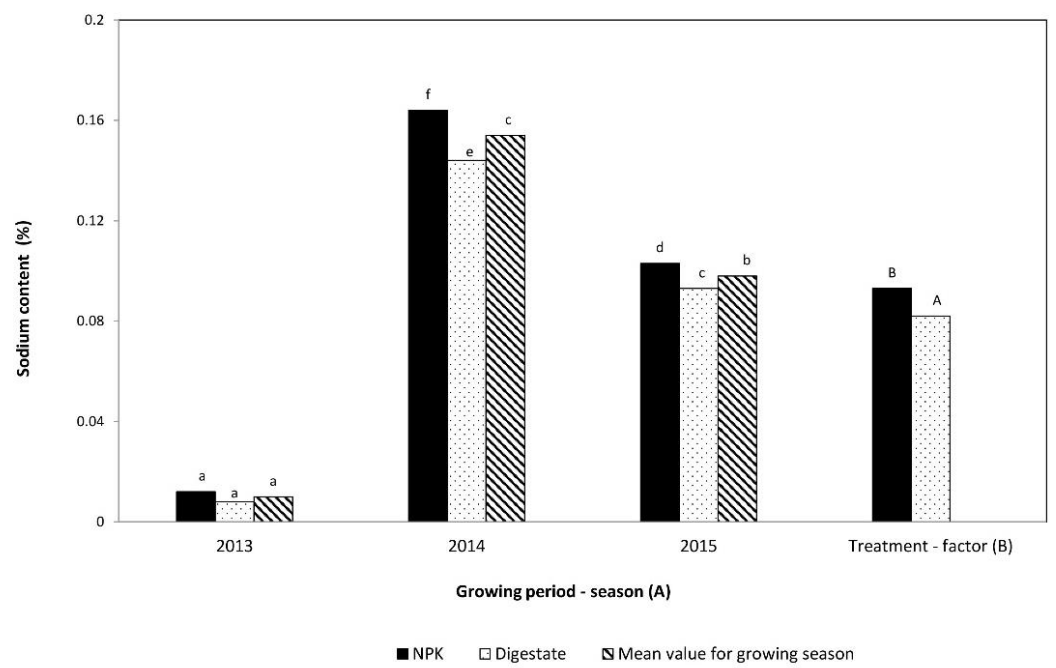

Figure 10. Effects of growing seasons and fertilization treatments on sodium content in sugar beet roots. 


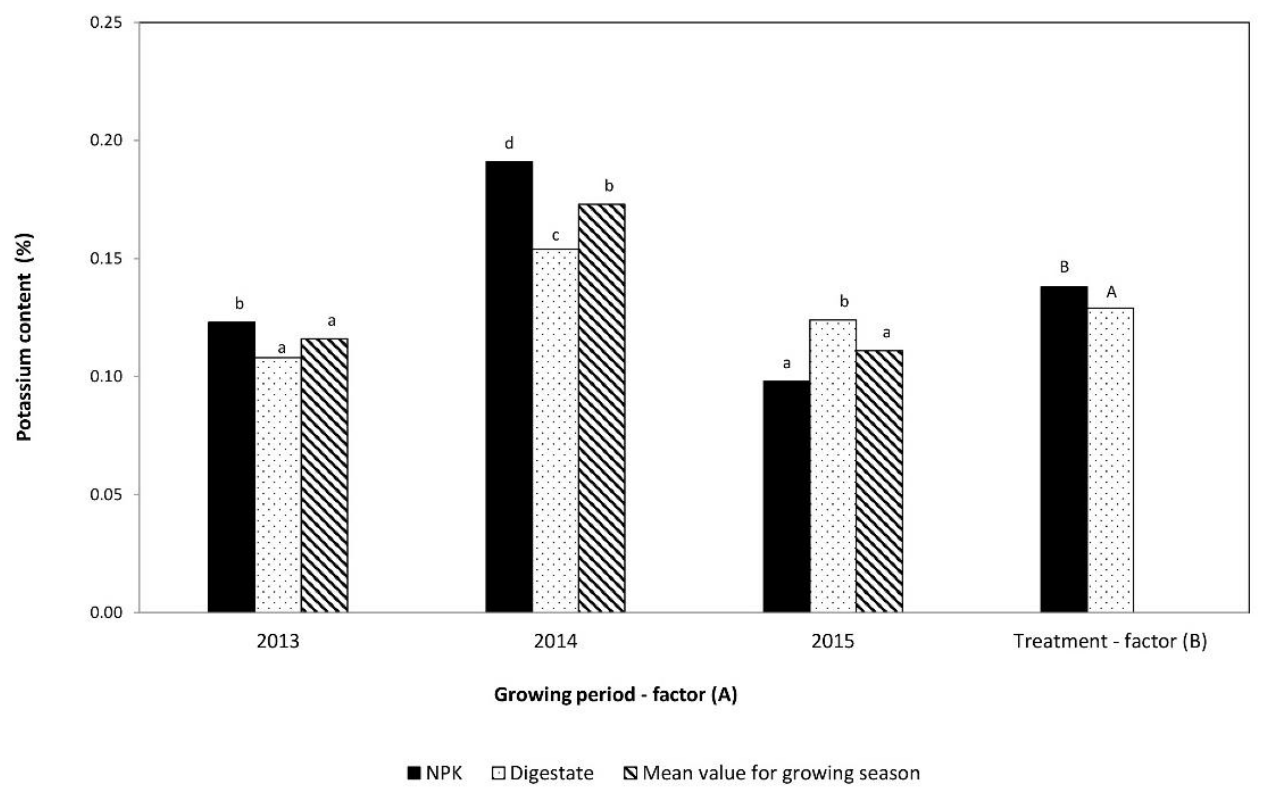

Figure 11. Effects of growing seasons and fertilization treatments on potassium content in sugar beet roots.

Most important quality parameters are weight of sugar beet together with sucrose content and in some sugar factories also content of $\alpha$-amino acids is routinely analysed. In the experiment the lowest weight of single root was noted in season 2014 and the highest in season 2013 what reflected the effect of weather conditions.

It was found that the weight of single root in 2014 growing season was not affected by studied fertilization treatments-average values were almost equal. Different impact of fertilization treatments on single root weight was found in the seasons 2013 and 2015. In 2013 significantly higher weight of single root was found for NPK treatment whereas in 2015 roots harvested from plots amended with digestate showed higher weight than roots from control treatment (Figure 4). This variability resulted in lack of significant differences when treatment effect was taken into account.

Applied digestate is a source of nutrient for growing crop but contrary to manures, composts and sewage sludge which have been extensively studied in the past research on digestates is not complex so far. Under conditions of Southern Sweden it was found that soil chemical properties were only slightly modified when soil was amended with some organic by-products including digestates [21]. Odlare et al. [21] reported that among studied amendments i.e., pig manure, cow manure, compost, inorganic fertilizer and digestate from household wastes soil treated with the last one manifested highest biomass and activity of studied microorganisms.

It was found improvement of quality of soils treated with anaerobic digestates in short term. Besides the beneficial impact on microbial biomass and content of essential nutrients also reducing soil bulk density and increasing its hydraulic conductivity have been pointed. However, it has to be mentioned that literature on this topic is relatively scarce $[27,28]$.

Content of sucrose accumulated in sugar beet roots should be regarded as relatively high because reported in Poland content of sucrose usually ranges between 14 and 19\% (30). In the current study it ranged between 17.3 and 18.6\%, for season 2014 and 2013, respectively. It was found that differences of sugar content in sugar beet roots were significant in relations to the season of studies and the highest was in 2013. Also fertilization treatment significantly affected sugar content and roots collected from plots amended with digestate showed higher by $0.5 \%$ sucrose content than roots from NPK treatment (Figure 5).

Data presented in Figure 6 show that content of dry matter in tissues of beet roots ranged from 22.3 to $24.2 \%$. I was revealed that differences of this key parameter in seasons 2013 and 2014 as well as 
average in three seasons were not proven and only in 2015 beets harvested from plots amended with digestate accumulated significantly more dry matter in roots than roots from NPK treatment.

It can be pointed out that content of dry matter in sugar beet roots obtained in the experiment was relatively high. Dobrzycki [29] reported that 25\% of DM in sugar beet roots is a typical value for sugar beets of high industrial quality.

What is worth to mention is the fact that over $80 \%$ of dry matter consist of sucrose irrespectively of fertilization treatment under studies what indicate high efficiency of sugar accumulation in sugar beets storage organs.

Soluble ash fraction represents mineral compounds contained in the juice and weakly bond to root tissues. During sugar extraction process soluble ash through draft juice reaches molasses. During processing this fraction is considered as beneficial for extraction because soluble ash consisting mainly of sodium and potassium stabilises $\mathrm{pH}$ of draft juice in a basic range [30].

Obtained results of analytical procedures showed generally low variability of average ash content in seasons of studies in sugar beet roots because it ranged from 0.28 to $0.35 \%$. In two seasons of studies (2013 and 2014) roots from plots amended with digestate showed significant decrease of soluble ash fraction comparing to beet from the other studied treatment (NPK (Figure 7).

Two analysed nitrogen species (Figures 8 and 9) are harmful for the technological process in sugar factories processing sugar beets. Amino acids negatively affect $\mathrm{pH}$ of juices and reactions between them and simple sugars undergo intensively and their products are undesirable colourful substrates. They are defined as "harmful no-sugar compounds". Amide compounds during thermal processes in during sugar extraction are degraded to ammonia what pollutes condensate which is pumped to steam boiler what makes the necessity of applying water purification operation. Also occurrence of amide compounds can result in presence of pyrrolidone carboxylic acid which negatively affect technological quality of juice. Moreover, amino acids molecules are substrates of so called Maillard reaction which gives brown products undesirable during white sugar production [31].

It was found that concentration of $\alpha$-amino acids nitrogen varied from 0.001 to $0.009 \%$ irrespectively of fertilization treatment but ANOVA results showed that in the season 2015 this nitrogen species content was significantly lower than in two other seasons of studies (Figure 8).

Variability of concentration of amide nitrogen content in sugar beet roots was related to the fertilization treatment in two seasons of studies (2014 and 2015). In tissues of sugar beets collected from plots amended with digestate significantly lower concentration of this nitrogen species was noted. It can be stated this method of soil fertilization of sugar beets using digestate resulted in lower content of harmful amide nitrogen comparing to standard mineral fertilizers (Figure 9).

Sum of both studied elements (sodium and potassium) represents so called "natural alkalinity". Sugar beet uses them to maintain $\mathrm{pH}$ value of juice between 5.8 and 6.2 what favours accumulation of high amount of sucrose. Sodium and potassium in ash represented a dominant fraction. During processing in sugar factory both elements play essential role in maintaining appropriate $\mathrm{pH}$ of extract of processed stock material. On the other hand, mentioned alkali metals compounds show high affinity to sucrose and increase sugar concentration in molasses what may result in higher losses of sucrose [30].

Relatively high variability of sodium content in seasons of studies was found because it ranged from 0.012 to $0.164 \%$ in 2013 and 2014, respectively. In two seasons (2014 and 2015) as well as on an average, sodium concentration in sugar beets from digestate treatment was significantly lower than in roots of beets fertilized with NPK (Figure 10).

Similar pattern was found in the case of second analysed alkali metal (potassium) i.e., significantly lower concentration under the effect of digestate comparing to application of standard mineral fertilizers i.e., NPK despite of the fact that in one season (2015) contrary effect was observed (Figure 11).

So it can be concluded that average concentration of sodium and potassium in sugar beets harvested in three subsequent seasons from plots amended with digestate can be regarded as beneficial for sugar processing. 
Summing up obtained results, it can be pointed out that soil application of liquid waste from anaerobic digestion of sugar beet pulp on sugar beet plantation showed its suitability as an alternative and safe method of management this waste.

\section{Conclusions}

1. Quality of digestate from process of anaerobic digestion of sugar beet pulp makes possible its utilization as soil amendment in terms of heavy metals content and pathogen occurrence.

2. Application of nitrogen at the rate of $120 \mathrm{~kg} \mathrm{~N} \mathrm{ha}^{-1}$ in the form of digestate resulted in high quality of sugar beet roots as a crop and as well as a stock material for sugar factory.

3. Analysis of variance showed significant effects of weather conditions on quality of sugar beets irrespectively of fertilization treatment. It was shown that values of majority of studied parameters were related to variability of conditions during growing seasons.

4. Digestate application to the soil did not negatively affect no quality parameter important for processing of sugar beet roots in sugar factory.

5. Soil application of digestate obtained from digestion of sugar beet pulp may be treated as a sustainable alternative solution for conventional technology of sugar beet growing and can be economically feasible.

Author Contributions: Conceptualization, A.B.; methodology, B.P. and A.K.; software, A.K.; formal analysis, A.B.; writing-original draft preparation, A.B.; writing—review and editing, A.K. and B.P. All authors have read and agreed to the published version of the manuscript.

Funding: This research received no external funding.

Conflicts of Interest: The authors declare no conflict of interest.

\section{References}

1. Połeć, B.; Baryga, A.; Szymański, T.; Wołyńska, W.; Toboła, A. Możliwość wytwarzania biogazu w procesie fermentacji metanowej wysłodków buraczanych. Gaz. Cukrow. 2011, 4, 107-112.

2. Brooks, L.; Parravicini, V.; Svardal, K.; Kroiss, H.; Prendl, L. Biogas from sugar beet press pulp as substitute of fossil fuel in sugar beet factorie. Water Sci. Technol. WST 2008, 58, 1498-1504.

3. Dulcet, E.; Ledochowski, P. Technique of ensilage of beetroot marc in the form of cylindrical beams wrapped in foil. J. Res. Appli. Agri. Eng. 2007, 52, 37-39.

4. Herrmann, C.; Prochnow, A.; Heiermann, M.; Idler, C. Biomass from landscape management of grassland used for biogas production: Effects of harvest date and silage additives on feedstock quality and methane yield. Grass Forage Sci. 2013, 69, 549-566. [CrossRef]

5. Hutnan, M.; Drtil, M.; Derco, J.; Mrafkova, L.; Hornak, M.; Mico, S. Two-step pilot-scale anaerobic treatment of sugar beet pulp. Pol. J. Environ. Stud. 2001, 10, 237-243.

6. Khanna, M.; Dhungana, B.; Clifton-Brown, J. Costs of producing miscanthus and switchgrass for bioenergy in Illinois. Biomass Bioenergy 2008, 32, 482-493. [CrossRef]

7. Murphy, J.D.; Power, N. Technical and economic analysis of biogas production in Ireland utilizing three different crop rotation. Appl. Energy 2009, 86, 25-36. [CrossRef]

8. Seppälä, M.; Paavola, T.; Lehtomäki, A.; Pakarinen, O.; Rintala, J.A. Biogas from energy crops-Optimal pre-treatments and storage, co-digestion and energy balance in boreal conditions. Water Sci. Technol. 2008, 58, 1857-1863. [CrossRef]

9. Ziemiński, K.; Kowalska-Wentel, M. Effect of enzymatic pretreatment on anaerobic co-digestion of sugar beet pulp silage and vinasse. Bioresour. Technol. 2015, 180, 274-280. [CrossRef]

10. Frąc, M.; Ziemiński, K. Methane fermentation process for utilisation of organic waste. Intern. Agrophys. 2012, 26, 317-330. [CrossRef]

11. Lalak, J.; Kasprzycka, A.; Murat, A.; Paprota, E.M.; Tys, J. Obróbka wstępna biomasy bogatej w lignoceluloze w celu zwiększenia wydajności fermentacji metanowej. Acta Agrophys. 2014, 21, 51-62.

12. Myszograj, S. Metan—Gaz cieplarniany i źródło energii. Ekotechnika 2005, 3, 53-55. 
13. Kasprzak, A.; Krzysiak, L. Biomasa jako cenny surowiec do produkcji biogazu. Lab. Przeglad Ogólnopolski 2007, 9, 60-62.

14. Kacprzak, A.; Michalska, K.; Romanowska-Duda, Z.; Grzesik, M. Rośliny energetyczne jako cenny surowiec do produkcji biogazu. KosmoProbl. Nauk Biol. 2012, 61, 281-293.

15. Bachmann, S.; Gropp, M.; Eichler-Löbermann, B. Phosphorus availability and soil microbial activity in a 3 year field experiment amended with digested dairy slurry. Biomass Bioenergy 2014, 70, 429-439. [CrossRef]

16. Berruto, R.; Busato, P.; Bochtis, D.; Sørensen, C.A.G. Comparison of distribution systems for biogas plant residual. Biomass Bioenergy 2013, 52, 139-150. [CrossRef]

17. Cirne, D.G.; Lehtomäki, A.; Björnsson, L.; Blackall, L.L. Hydrolysis and microbial community analyses in two-stage anaerobic digestion of energy crop. J. Appl. Microbiol. 2007, 103, 516-527. [CrossRef]

18. Chen, R.; Blagodatskaya, E.; Senbayram, M.; Blagodatsky, S.; Myachina, O.; Dittert, K.; Kuzyakov, Y. Decomposition of biogas residues in soil and their effects on microbial growth kinetics and enzyme activities. Biomass Bioenergy 2012, 45, 221-229. [CrossRef]

19. Paprota, E. Proces fermentacji metanowej sposobem otrzymywania pełnowartościowego nawozu organicznego. In Materiaty z Seminarium Naukowego Popularyzacja Prac Badawczo-Rozwojowych z Zakresu Odnawialnych Źródeł Energii; Ekspert-SITR Spólka z o.o.: Lublin, Poland, 2012.

20. Jędrczak, A. Biologiczne Przetwarzanie Odpadów; PWN: Warszawa, Poland, 2008; p. 456. ISBN 978-83-01-15166-9.

21. Odlare, M.; Pell, M.; Svensson, K. Changes in soil chemical and microbiological properties during 4 years of application of various organic residues. Waste Manag. 2008, 28, 1246-1253. [CrossRef]

22. Gunnarsson, A.; Lindén, B.; Gertsson, U. Biodigestion of plant material can improve nitrogen use efficiency in a red beet crop sequence. HortScience 2011, 46, 765-775. [CrossRef]

23. Nges, I.A.; Björn, A.; Björnsson, L. Stable operation during pilot-scale anaerobic digestion of nutrient-supplemented maize/sugar beet silage. Bioresour. Technol. 2012, 118, 445-454. [CrossRef]

24. Artyszak, A. Ile zostaje z buraków cukrowych? Nowocz. Uprawa 2009, 11, 24-25.

25. Nowacki, J. Available online: http://kalkulacje.wodr.poznań.pl/buraki1.htm (accessed on 16 December 2016).

26. Butwiłowicz, A. Metody Analityczne Kontroli Produkcji w Cukrowniach; Fundacja Rozwój SGGW: Warszawa, Poland, 1997.

27. Garg, R.N.; Pathak, H.; Das, D.K.; Tomar, R.K. Use of Flyash and Biogas Slurry for Improving Wheat Yield and Physical Properties of Soil. Environ. Monit. Assess. 2005, 107, 1-9. [CrossRef]

28. Nkoa, R. Agricultural benefits and environmental risks of soil fertilization with anaerobic digestates: A review. Agron. Sustain. Dev. 2013, 34, 473-492. [CrossRef]

29. Dobrzycki, J. Chemiczne Podstawy Technologii Cukru [Chemical Basis of Sugar Production-In Polish]; WNT: Warszawa, Poland, 1984; p. 395. ISBN 978-83-20-40634-4.

30. Waleriańczyk, E. Kompendium Praktycznego Prowadzenia Procesu Ekstrakcji w Aparacie Korytowym; STC: Warszawa, Poland, 1996.

31. Laudański, A. Układ Cieplno-Technologiczny, Organizacja i Sposób Oceny. Energetyka Cieplna Cukrowni. cz. 1; Wydawnictwo Naukowe Askon: Warszawa, Poland, 2001.

Publisher's Note: MDPI stays neutral with regard to jurisdictional claims in published maps and institutional affiliations.

(C) 2020 by the authors. Licensee MDPI, Basel, Switzerland. This article is an open access article distributed under the terms and conditions of the Creative Commons Attribution (CC BY) license (http://creativecommons.org/licenses/by/4.0/). 